\title{
Economic Goals for 1981: A Monetary Analysis
}

\author{
KEITH M. GARLSON
}

\begin{abstract}
I
$\triangle O N G-R A N G E$ economic planning in the United States began in calendar 1975 with the preparation of the fiscal 1976 Federal budget. ${ }^{1}$ Since then, each budget document has included economic assumptions and budget projections for a five-year horizon." For example, the fiscal 1978 budget, for which estimates were first prepared in January 1977 and then revised in July 1977, includes assumptions and projections through 1982. The assumptions for the current year and the next are called "forecasts," but beyond the next year the assumptions are labeled as "projections consistent with moving gradually toward relatively stable prices and maximum feasible employment."3 In other words, for the longer run, the assumptions for output growth, inflation, and unemployment can be viewed as macroeconomic goals.
\end{abstract}

The Carter Administration's national economic goals for 1981 include: ${ }^{4}$

1. a reduction of unemployment to 4.75 percent of the labor force from the current level of abont 7 percent;

2. a reduction in the rate of inflation to a 4.3 percent annual rate;

3. a balance in the Federal budget at expenditure and revenue levels equal to 21 percent of CNP.

Although the Administration is explicit in its specification of fiscal policy assumptions for the period 1977 through 1981, it says nothing about its monetary

\footnotetext{
1Presentation of the Aclministration's long-run budget projections and economic assumptions is required under the provisions of the Congressional Budget and Impoundment Control Act of $197^{7 / 2}$.

-For a summary of the year-by-year economic assmmptions that have been made thus far, see Table 1 .

3The short-term assumptions are presented as forecasts of probable econonic conditions whereas the longer range assunptions are "tnechanical projections." The difference is that "forecasts" are best guesses as to likely outcomes, taking into acconnt all factors impinging on the economy (inchuding extemal shocks, e.g., changes in oil prices). Long run as" sumptions (or projections) are based on systematic and predictable inthences on economic activity, and thus do not reflect an attempt to predice the occurrence of extemal shocks or changes in economic structure. See The Budget of the United States Govenment, Fiscal Year 1976 (Washing ton, D.C.: U.S. Government Printing Office, 1975).

toffee of Management and Budget, Mid Session Reriew of the Fiscal 1978 Budget (July 1, 1977). Also see Remarks by Charles L. Schultze, Chaiman, Council of Economic Advisers, to New York Financial Writers Association (May 18, 1977). Although projections are presented through 1982 , the Administration focuses its discussion on 1981 .
}

policy assumptions. Furthermore, details about the structure of its underlying economic model are not made explicit.

A unique feature of the goals of the current Administration is the self-imposed constraint on the growth of Federal spending and the goal of budget balance. Budget goals had been set forth in general terms in earlier budgets, but previous budgets did not specifically state a desire to achieve a balanced budget, nor did they impose the additional constraint of limiting the size of Federal spending to a stated percentage of GNP. The emergence of this goal might be related to the persistence of large Federal deficits in recent years, and, in particular, the coneern expressed by the financial and business community about their magnitude.

\section{RVAUUATON PROCEDURE}

Although the Administration does not provide information about its underlying model, it is essential to examine the long-range goals within the context of a particular analytical framework. The question asked here is whether the set of economic goals is consistent with a monetarist model of the U.S. economy. The model which is used is a modified form of the " $\mathrm{St}$. Louis model." The chief modification is the use of a newly developed potential output series.

Since the Administration does not make its assumptions about monetary policy explicit, its goals are first examined to determine their implications for monetary growth. In a monetarist framework, such assumptions are critical, and in the monetary model used here, changes in money are the primary driving force.

The St. Louis model includes direct determination of GNP, via a reduced form equation, relating the

\footnotetext{
"For a smilar analysis of the administration's 1981 goals using the Wharton model (University of Pensylvatia) see Thomas $F$. Dembury and L. Douglas Lee, "The Macrom economic Goals of the Administration for 1981: Targets and Realizations" A Study Prepared for the Use of the Joint Economic Committee (August 5, 1977). See insert.

"A detailed summary of these modifications is available upon request. For a discussion of the original model see Leonall $\mathrm{C}$. Andersen and Keith M. Carlson, "A Monetarist Model for Economic Stabilization," this Roview (Aprit 1970), pp. 7-25. TRobert H. Rasche and Johm A. Tatom, "Energy Resources and Potential GNP," this Review (June 1977), pp. 10-24.
} 
Table:



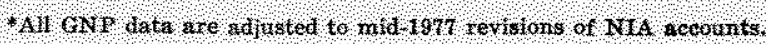

change in GNP to current and past changes in money and high-employment Federal expenditures. Estimates of the equation indicate that over a period of a year or more, steady growth in Federal spending in the absence of changes in the rate of monetary expansion has little net effect on the growth rate of GNP. The primary factor determining the growth of GNP over a period of a year or more is the trend of money and the trend of velocity as embodied in the estimated constant term. ${ }^{8}$

\footnotetext{
8These results regarding fiscal actions remain in dispute. See Benjamin M. Friedman, "Even the St. Lonis Model Now Believes in Fiscal Policy, Journal of Money, Credit and Banking (May 1977), pp. 365-67. Friedman's results follow from an updated estimation of the GNP equation in first difference (arithmetic) form. The conclusion about the net effect of fiscal actions being near zero continues to hold when the equation is estimated in log first difference form. Analysis of the two specifications indicates that the log first difference form shows greater coefficient stability over time than does the arithmetic first difference form.
}

The change in GNP is divided between price and output change via a price equation. This price equation gives the change in prices as a function of current demand pressure and the recent history of price change. Over the long run, however, estimated price change is dominated by the trend of money growth, since the growth of total spending (driven by money) is the chief determinant of demand pressure. Given the change in GNP and prices, output change is found as a residual.

The final three equations of the model determine the unemployment rate and long- and short-term interest rates. Changes in output are used to estimate the unemployment rate via Okun's law. ${ }^{9}$

"Artherr M. Okun, "Potential GNP: Its Measurement and Significance," 1962 Proceedings of the Business and Economic Statistics Section of the American Stafistical Association, pp. 98-104, Oknn's Law relates the anemployment rate 


\section{THE DERNBURG-LEE STUDY: A COMMENT}

In a recent study prepared for lle loint Econonic

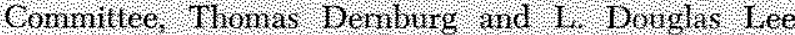
used the Wharton nodel to vnalyze the A lmmintra

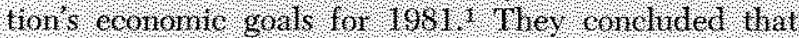
attaintment of all tho goals simnllanebnalt was not prosible. The reasoning inder ying IIIs conchision was as follows:

(1) becalise winding lown ifllation would re guire restrictive nonetary and $\mathrm{Gseal}$ polleies it is questionable whether the growl and envlovment targets are compatible with the inllation larget

(2) sinee balancing the bildget in 1981 would fequire relatively restirative fiscal policy after fiscal 1978 . Whe enployment larget nity be meompatble will a balanced budget,

(3) because nonetary polley would lave to be exprisioniary to reall the enulownent and 1,alanced budget targets, he willation tate night nse abowe he trued level.

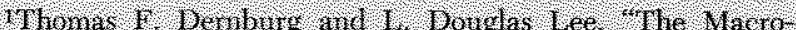

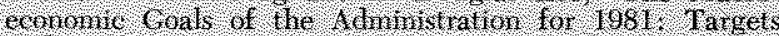

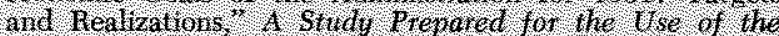
Joint Lconomic Commither ( 4 ugust 5, 1977):

\section{ANALISIS OF THE ADMINISTRATION'S 1981 GOALS}

For purposes of evaluating the Administration's 1981 economic goals the crucial assumption in the St. Louis model is the growth of money. By examining the relations between money and GNP, money and prices, and money and interest rates, the consistency of the Administration's goals can be checked. Furthemore, the budget constraints can be examined to see if they are simultaneously attainable. The reader is reminded that these simulations of the St. Louis model do not incorporate the effects of possible extemal shocks, and thus should not be considered as forecasts. Such an exercise is based on the assumption that average relationships of the past will hold in the future, and an evaluation of the consistency of future goals is conducted within that context.

\section{Money and GNP}

The Administration has set a goal for nominal GNP of $\$ 2,873$ billion for 1981 (see Table II). GNP would have to grow at a 10.9 percent average annual rate from 1977 to 1981. Given past relationships between money and GNP, the money stock (M1, that is, currency plus demand deposits) would have to grow at

to the gap between actual output and an estinate of potential outpnt.
These condistons sound reasonable and ho not differ swbstantiall from those rerched via the St. Wouts nodel. 11.6 polley inplications of We Denburg l.ee stidy however , ellect nore acemately the differences be ween the Wint ton and St, I our model t They con dude that becanse of 1 he $b 4 \mathrm{dget}$ terget, fill employ ment can be actieved only by aggressibe resort to moletart policus Aceording to smulations of the

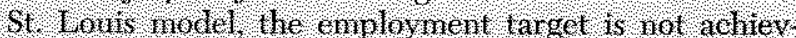

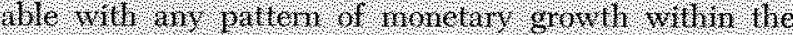
hinge of histoncal experience

The reason the mplication fer nometary policy is so dilferent is that the Detrbugt lee stidy assmes the inflation tele $l 0$ be exogenaus. And sinee the transmis sion nedlantrn of the Whatwen nodel works through 110 broxth of real moner halanees an inctease of

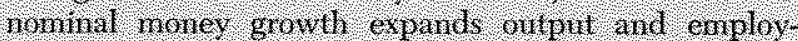
nent becalse hurased real nomey reduces interest tales and stimilales real speriling. The Dernburg Lee conclusions are seriolish Hawed becanse lher ovellobk he causal relationship beh ween noney and phices?

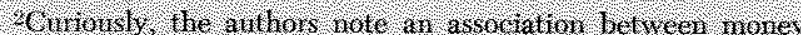

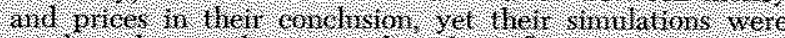
concheted in sueh a vay hiat the iffation rate was hot

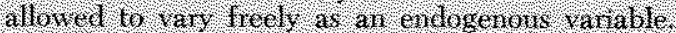

about a 7.1 percent annual rate from current levels (third quarter 1977) in order for such a GNP goal to be realized (see Table III).

It is also informative to examine the year-by-year path to this GNP goal in 1981. The Administration has laid out a path whereby the growth of GNP is faster in the earlier years then slows toward the end of the planning period. These growth rates are shown in Table IV. According to the St. Louis model, such a pattem of GNP growth would require the growth rate of money to be faster than 7.1 percent until late 1979 (see Table IV).

For purposes of analysis, two basic simulations are conducted in order to determine the consistency of the remaining variables. One is a steady growth of money from mid-1977 to 1981 (summarized in Table III), and the other is rapid growth of money in the early years, with a tapering in the growth rate to about 6 percent in 1981 (summarized in Table IV).

\section{Money and Prices}

The relationship between money and prices is a well-established one. ${ }^{10}$ However, this relationship is

\footnotetext{
10See Denis S. Karnosky, "The Lank Between Money and Prices $1971-76$, this Review (June 1976), pp. 17-23 and Richard T. Selden, "Intlation: Are We Winning the Fight," The Morgan Guaranity Survey (October 1977), pp. 7-13.
} 


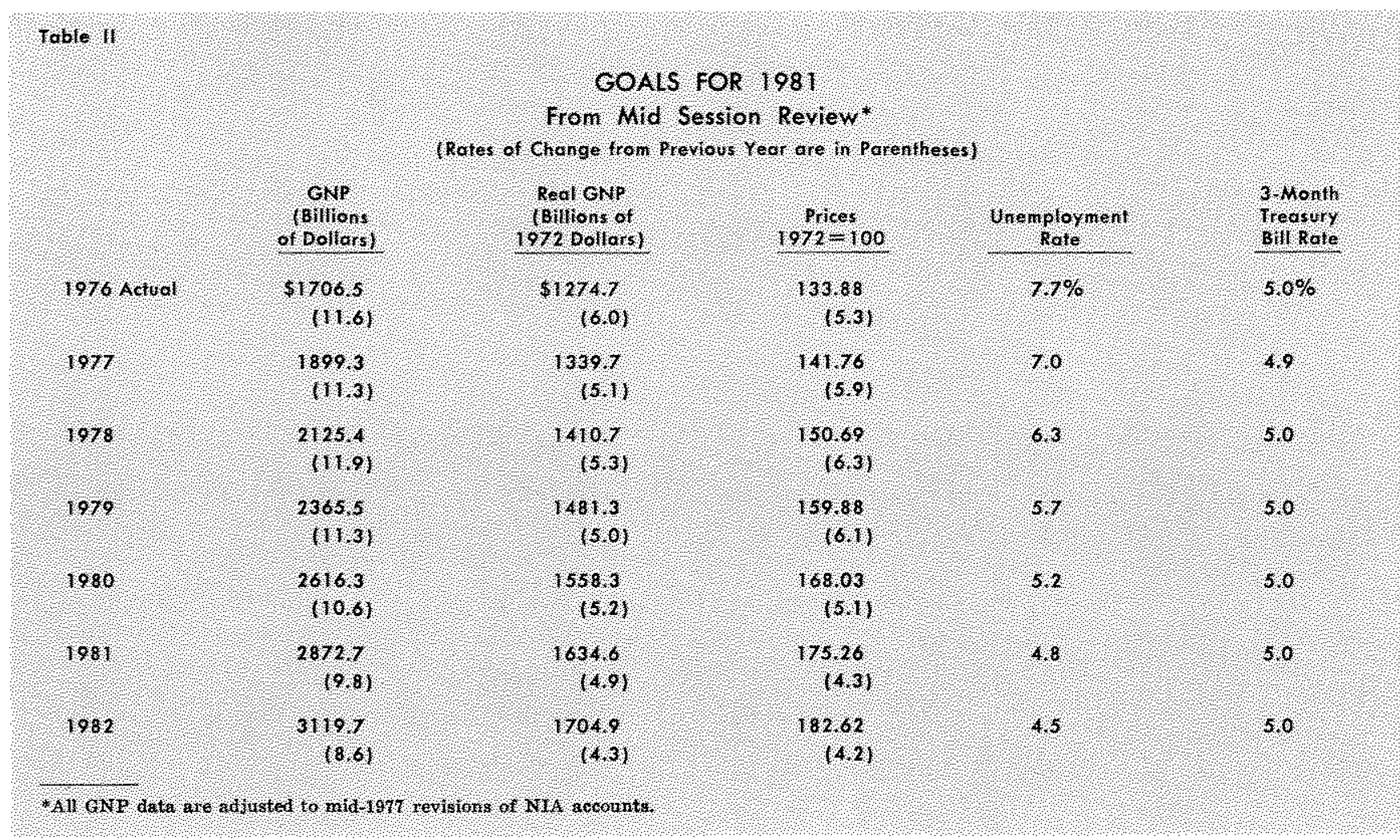

not given explicit treatment by the Administration in its discussion of long-range goals. For the period 1977 to 1981, the Administration sees an average annual rate of increase in prices of 5.4 percent, with the increase more rapid from 1976 to 1978 , but slowing to a 4.3 percent rate by 1981 . Examination of alternative simulations of the St. Louis model indicates that a 5.4 percent average rate of increase of prices from 1976 to 1981 is consistent with about a 5 percent trend growth of money. This points out a discrepancy between money growth implied by the GNP projection (7.1 percent) and that implied by the price projection ( 5 percent).

Consider now the inflation implications of the growth in money that would yield the Administration's 1981 GNP goal. Simulation with a steady 7.1 percent growth of money shows that prices will increase at a 7 percent average rate from 1977 to 1981 (see Table III). But more significantly, the dynamics of the model suggest that the rate of inflation wonld be ac celerating in 1981, as opposed to the Administration's contention that inflation would be decelerating.

Consider, on the other hand, the effects of an early acceleration of money followed by a slowing, a pattern apparenty more consistent with the Administration's tine path of GNP to 1981. Based on this assumed pattern of money growth, the inflation rate would be even greater than in the simulation using steady money growth, averaging 7.3 percent per year for 1977 to 1981 (see Table IV). The dymamics of the model suggest that the effect of the rapid growth in money from 1977 to 1979 on the inflation rate is still very much present in 1981, with the rate exceeding 9 percent.

\section{Outpat and Unemployment}

According to the St. Louis model, output over the longer run is determined by real factors in the economy - growth of the labor force, work-leisure preferences, capital growth, and technology. What happens to money growth on average over the next four years is of minor conseguence for the growth of output in 1981. However, the internal dynamics of the St. Louis model suggest output would still be in the process of adjusting to its longurun equilibrium rate five years after a current change in the growth rate of money. As a result, the growth of output in 1981 does differ somewhat for alternative growth rates of money.

The Administration's real GNP goal for 1981 is $\$ 1,635$ billion ( 1972 dollars). This is an average annual rate of increase from 1977 of 5.1 percent. Simulation 
Table III

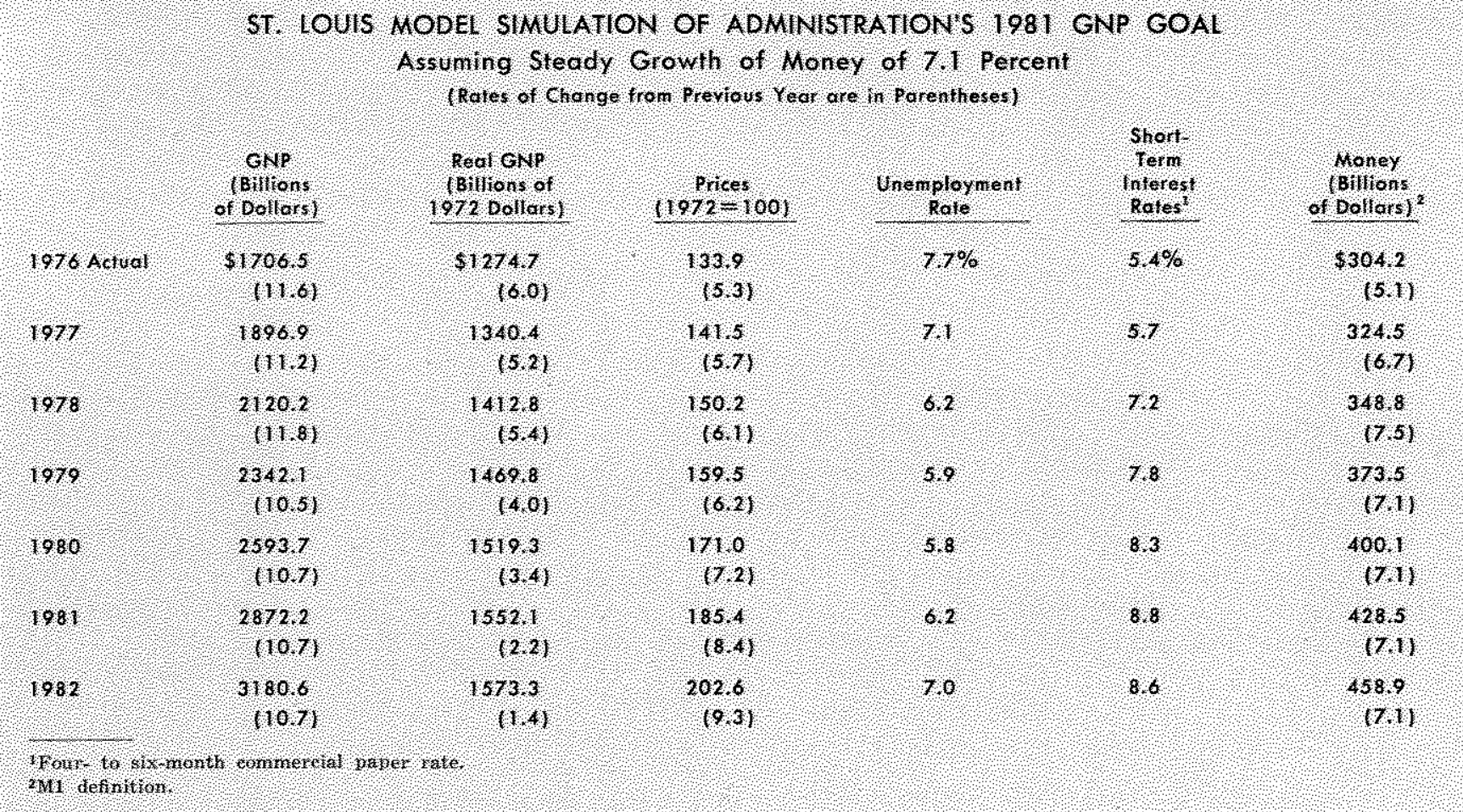

of the St. Louis model with a steady 7.1 percent growth of money indicates an average growth of output of 3.7 percent, which falls $\$ 83$ billion ( 1972 dol- lars) short of the Administration's goal (see Table III). With altemative simulations of steady growth rates of money of 2 through 9 percent, it was impos-

\begin{tabular}{|c|c|c|c|c|c|c|}
\hline & $\begin{array}{l}\text { ST LIC } \\
\text { Assum } \\
\text { anp } \\
\text { GBilons } \\
\text { of Dollors) }\end{array}$ & 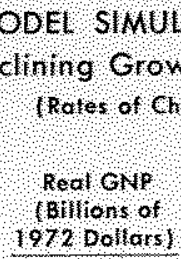 & 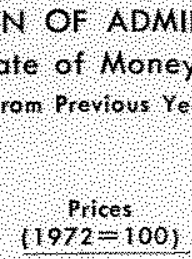 & 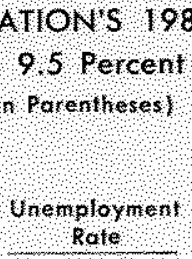 & 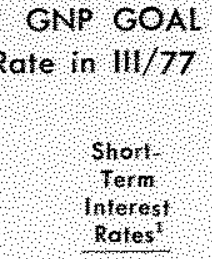 & $\begin{array}{l}\text { Money } \\
\text { (Bifliots. } \\
\text { of Dolfors) }\end{array}$ \\
\hline $1976 \mathrm{Acual}$ & 817065 & 512747 & 1339 & $77 \%$ & $5,4 \%$ & $\begin{array}{l}\$ 3042 \\
\quad 15,1\end{array}$ \\
\hline 197 & $\begin{array}{l}10978 \\
11,21\end{array}$ & $\begin{array}{r}134,0 \\
152\end{array}$ & 1415 & 71 & 56 & 324.9 \\
\hline $19 \%$ & 2127 & $\begin{array}{l}147, \\
15,1)\end{array}$ & $\begin{array}{l}150.2 \\
(6,1)\end{array}$ & 61 & 73 & $\begin{array}{l}350,0 \\
17,7)\end{array}$ \\
\hline 1979 & 23638 & 880, & 159. & 57 & 81 & $\begin{array}{l}372, \\
1781\end{array}$ \\
\hline 1980 & $\begin{array}{r}267 \% \\
110,7)\end{array}$ & 1524.4 & $\begin{array}{l}1720 \\
1761\end{array}$ & 56 & 91 & $\begin{array}{l}403.0 \\
16.01\end{array}$ \\
\hline 1981 & $\begin{array}{r}2070,5 \\
10,7\end{array}$ & $\begin{array}{l}5327 \\
10,51\end{array}$ & $\begin{array}{l}1876 \\
1911\end{array}$ & 65 & 92 & $\begin{array}{l}27.0 \\
1601\end{array}$ \\
\hline 1982 & 3197 & $\begin{array}{l}1520,7 \\
(0,0)\end{array}$ & 205.5 & 8,2 & 78 & 486, \\
\hline
\end{tabular}

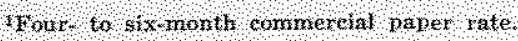
Ma defintion 
sible to simulate results yielding both the Administration's 1981 GNP and output goals. The alternative simulation with early acceleration of money followed by later slowing shows an average rate of output growth of 3.4 percent (slower than for the steady 7.1 percent case) because inflation intensifies earlier (see Table IV). Consequently, according to the St. Louis model, achievement of the Administration's goals for nominal GNP will probably result in more inflation and less output growth than the Administra. tion desires.

Given that output growth falls substantially short of the Administration's goal in this model, the unemployment rate also falls short of the 4.75 percent target. The 7.1 percent money growth simulation indicates an unemployment rate of 6.2 percent in 1981 (Table III). The alternative simetlation (variable growth pattern of money) indicates an even higher rate of unemployment of 6.5 percent (Table IV). If the Administration should attempt to achieve its unemployment goal (or, say, a more ambitious goal as suggested by the Humphrey-Hawkins bill) with only aggregate demand policies, more inflation will probably result.

\section{Money, Prices, and Interest Rates}

Although not so fundamental as a part of the Administration's goals, it is worth noting that the interest rate pattern of the St. Louis model indicates another area of inconsistency in the Administration's set of goals for 1981. The Administration indicates an assumption of a steady 5.0 percent yield on 3 -month Treasury bills throughout the planning period. If money growth is held at 7.1 percent to achieve the 1981 GNP target, the inflation implications are such that short-term interest rates can be expected to approach 9.0 percent by 1981. A similar result is associated with the alternative simulation using a variable growth pattem of money.

\section{Implications for the Federal Budget}

The Federal budget projections are, of course, an input to this process of long-run planning. The only aspect that is checked here is the effect of the longrange plan on real Federal outlays. According to the mid-session review of the budget, 1981 ontlays are targeted at 20.2 percent of GNP. The goal for GNP implies a level of receipts such that a surplus of $\$ 50$ billion is implied with current tax laws. ${ }^{11}$ Even if the

\footnotetext{
11Receipts estimates assume enactment of the Administration?s proposals as of Juty 1977 and incude energy provosals and the effect of schetuled increases in the unemploynent
}

expenditure level were equal to 21 percent of GNP, a $\$ 30$ billion surplus would still be implied. The reasons for such a surplus are twofold: One, the inflationary experience has boosted the relative importance of the individual income tax (a tax which is very responsive to changes in nominal income) in the U.S. tax structure, and, two, receipts estimates include tax increases for social security and those incorporated in the proposed energy program.

Furthermore, if the GNP target is achieved and expenditures reach their projected level, an implication of the St. Louis model is that real Federal outlays would increase at a 0.4 percent average annual rate, instead of the 1.0 percent rate that the Administration projects. By comparison, real Federal outlays rose at a 4.5 percent average rate in the previous five-year period from 1971 to 1976.

\section{SUMMARV AND CONCUUSTONS}

The Administration has presented a set of national economic goals for 1981, continuing a process of longrange planning begun over two years ago. Exactly how these assumptions are used in the policymaking process is not clear, but presumably departures from plan suggest that the Administration believes that policy actions should then be taken. Consequently, it is important that such goals be stbjected to scrutiny.

Using as a starting point a growth of money that would achieve the Administration's GNP goal for 1981, it was found that based on past relationships, the goals for prices, output, unemployment, and interest rates probably are not achievable simultaneously. Furthermore, the discrepancies are substantial. No ftndamental inconsistency was found relating to the budget goals of restrained expenditure growth and at least a balanced budget, but the implication is that the implied growth of real Federal expenditures is somewhat less than indicated in the longurange plan and much below the growth in the recent past.

Presentation by the Federal Government of its long-range goals is laudable. The St. Louis model does, however, indieate unequivocably that the Administration's goals are not achievable given the current structure of the economy. Furthermore, an attempt to use aggregate demand management to attain the stated goals regarding output growth and tinemployment will impart substantial damage to the economy by causing infation to accelerate. Eventually such policies will cause an increase in unemployment.

insurance tax base and the social security tax rate and base. The effect of proposed tax reforn is not included. 